\title{
Cytoreductive Surgery and Hyperthermic Intraperitoneal Chemotherapy for Peritoneal Metastasis from Breast Cancer: A Preliminary Report on 4 Cases
}

Jun-Hui Yu

Beijing Shijitan Hospital, Capital Medical University

Yu Feng

Beijing Shijitan Hospital, Capital Medical University

Xin-Bao Li

Beijing Shijitan Hospital, Capital Medical University

Cheng-Yan Zhang

Beijing Shijitan Hospital, Capital Medical University

Feng Shi

Beijing Shijitan Hospital, Capital Medical University

Song-Lin An

Beijing Shijitan Hospital, Capital Medical University

Gang Liu

Beijing Shijitan Hospital, Capital Medical University

Yan-Bin Zhang

Beijing Shijitan Hospital, Capital Medical University

Kai Zhang

Beijing Shijitan Hospital, Capital Medical University

\section{Zhong-He Ji}

Beijing Shijitan Hospital, Capital Medical University

\section{Bing Li}

Beijing Shijitan Hospital, Capital Medical University

\section{Guo-Jun Yan}

Beijing Shijitan Hospital, Capital Medical University

\section{Yan-Ping Li}

Beijing Shijitan Hospital, Capital Medical University

Yan Li ( $D$ liyansd2@163.com )

department of peritoneal cancer surgery, Beijing Shijitan Hospital affiliated to the captial medical university, Beijing, 100038,China 
Research

Keywords: Breast cancer, Cytoreductive surgery, Hyperthermic intraperitoneal chemotherapy $\rrbracket$ Peritoneal carcinomatosis

Posted Date: August 14th, 2020

DOI: https://doi.org/10.21203/rs.3.rs-57235/v1

License: (c) (i) This work is licensed under a Creative Commons Attribution 4.0 International License.

Read Full License

Version of Record: A version of this preprint was published at Gland Surgery on April 1st, 2021. See the published version at https://doi.org/10.21037/gs-20-893. 


\section{Abstract}

Background: Breast cancer (BC) has the highest morbidity and the fifth mortality rate among women in China. Peritoneal metastases from $\mathrm{BC}$ is a rare disease and no guideline or international consensus for it.

Objective: To summarise our experiences in cytoreductive surgery (CRS) and hyperthermic intraperitoneal chemotherapy (HIPEC) to treat breast cancer peritoneal carcinomatosis (BC PC).

Methods: 4 BC PC patients underwent CRS+HIPEC were enrolled in this study. The clinic-pathologic characteristics and overall survival (OS) were collected and analysed.

Result: The average age at CRS+HIPEC was 59.8 years. The average time of CRS+HIPEC was $8.8 \mathrm{~h}$. The median number of resected organ areas was 7. OS from CRS+HIPEC were 31, 28, 16 and 52 months. There were no serious adverse events (SAEs) during the perioperative period.

Conclusions: The 4 cases provided evidence that integrated therapy with CRS+HIPEC may be a promising strategy to improve the outcome for BC PC patients.

\section{Background}

Breast cancer (BC) has been ranked as the first malignancy in incidence and the fifth mortality rate among women in China [1]. The five-year survival of $B C$ has been increasing but the treatment of recurrent $B C$ is a challenge [2-5]. Typical metastasis sites of $B C$ in order of frequency were bones(67.8\%), liver(47.8\%), lungs(42.6\%), brain(15.2\%) and peritoneum (7.6\%) [6-7]. Chemotherapy and estrogen therapy were the main treatments for peritoneal carcinomatosis from BC (BC PC), with the median OS was 28 months [4].

At present, for peritoneal carcinomatosis from gastrointestinal tumors or gynecological tumors, cytoreductive surgery (CRS) plus hyperthermic intraperitoneal chemotherapy (HIPEC) have been recommended as the standard treatment. The detailed process and safety of CRS plus HIPEC in BC PC was the lack in the literature.

Here we report 4 BC PC cases with multiple therapeutic modalities, including CRS + HIPEC to determine the role of CRS + HIPEC in BC PC.

\section{Patients And Methods}

\section{Clinical information}

From January 2015 to March 2020, a total of 893 BC patients have underwent radical resection at Beijing Shijitan Hospital, 17 of which have progressive disease with PC. There are 4 BC PC patients who underwent CRS + HIPEC enrolled in this retrospective study. Another 13 patients with BC PC had exclusion 
criteria or disagreed the CRS + HIPEC and were not enrolled. The diagnosis of BC PC is confirmed by pathology in all patients.

The study design was approved by the Ethical Committee of the Beijing Shijitan Hospital. All patients were introduced to the detailed process of CRS + HIPEC and signed informed consent.

CRS + HIPEC were the standard treatment for PC and had formed a standard clinical path, including detailed inclusion and exclusion criteria.

Inclusion criteria: (1) patients had a computed tomography of the abdomen with BC PC and pathological confirmation; (2) Karnofsky performance status (KPS) score $\geq 60$; (3) liver function: bilirubin $\leq 2 \times$ the upper limit of normal (ULN) and aspartic aminotransferase and alanine aminotransferase $\leq 2 \times$ ULN; (4) renal function: serum creatinine $\leq 1.2 \times \mathrm{ULN}$; and (5) cardiovascular pulmonary and other major organ functions could stand major operation.

Exclusion criteria: (1) bones, liver, lungs, brain or other distant metastases; (2) serum bilirubin, aspartic aminotransferase and alanine aminotransferase level > $2 \times$ ULN; (3) serum creatinine level > $1.2 \times$ ULN; (4) total gastrointestinal angiography indicating significant mesenteric contracture; (5) cardiovascular pulmonary and other major organ functions cannot stand major operation [8].

\section{CRS + HIPEC procedure}

All CRS + HIPEC were conducted by the same professional PC treatment team. Peritoneal cancer index $(\mathrm{PCl})$ was evaluated through the nature of ascites, tumor size and location after cutting the abdominal cavity [9] (Fig. 1A). Subsequently, according to the peritonectomy procedures by Sugarbaker, the curative or palliative resection, peritonectomy, lymphadenectomy to maximal CRS [10]. Completeness of cytoreduction (CC) was evaluated based on residual tumor size [11] (Fig. 1B). HIPEC was carried out immediately after CRS intraoperatively. The HIPEC regimen consisted of docetaxel $120 \mathrm{mg}$ plus cisplatin $120 \mathrm{mg}$. The HIPEC was conducted through the open Colliseum technique [8].Each drug was added to $3 \mathrm{~L}$ saline and heated to $43 \pm 0.5^{\circ} \mathrm{C}$. The HIPEC time for each drug was 30 minutes and the flow rate was $400 \mathrm{ml} / \mathrm{min}$. Gastrointestinal tract reconstruction, abdominal drainage tube placement and tension reduction suture incision were performed after HIPEC [12].

\section{Study endpoint}

The primary endpoint was the OS from CRS + HIPEC. The secondary endpoint was the perioperative safety of CRS + HIPEC in BC PC.

\section{Definition}

1. $\mathrm{OS}_{1}$ was defined as the day from diagnosis $\mathrm{BC}$ to the day of death or related with $\mathrm{BC} \mathrm{PC}$ or the last follow-up; $\mathrm{OS}_{2}$ was defined as the day from CRS + HIPEC to the day of death or related with BC PC or the last follow-up.

2. The perioperative period was defined as 30 days after CRS + HIPEC [12]. 
3. Adverse events (AE) were defined according to the Clavier-Dindo classification system: Grade I: Any deviation from the normal postoperative course without the need for pharmacological treatment or surgical, endoscopic, and radiological interventions; Grade II: Requiring pharmacological treatment with drugs other than such allowed for grade I complications; Blood transfusions and total parenteral nutrition are also included; Grade III: Requiring surgical, endoscopic or radiological intervention; Grade IV: Life-threatening complication requiring intermediate care (IC)/ intensive care unit (ICU) management; Grade V: Death of a patient. SAEs were defined as the grade III-V AEs [13-14].

\section{Follow-up}

1) Patients were followed up every 3 months for the first 2 years and every 6 months thereafter; 2) Followup items included: physical examination, tumor markers, breast and gynaecological color Doppler ultrasound, chest and abdomen computed tomography (CT); 3) The last follow-up date was March 1 , 2020 , with the rate of $100 \%$.

\section{Results}

\section{Major clinicopathological characteristics}

All 4 patients were female. The average age was 59.8 (50-65) years at CRS + HIPEC. In terms of pathology, there were 1 case with ILC and 3 cases with IDC. Molecular typing of primary tumors of all 4 cases was Luminal B. The major clinicopathological characteristics of primary BC and metastasis PC were shown in Table 1. 
Table 1

Major clinicopathological characteristics of primary BC and metastasis PC

\begin{tabular}{|c|c|c|c|c|}
\hline Characteristics & Case 1 & Case 2 & Case 3 & Case 4 \\
\hline $\begin{array}{l}\text { Age at diagnosis of } \\
\text { breast cancer, years }\end{array}$ & 50 & 60 & 53 & 50 \\
\hline Gender & Female & Female & Female & Female \\
\hline $\begin{array}{l}\text { Breast tumor } \\
\text { localisation }\end{array}$ & Left & Right & Right & Left \\
\hline $\begin{array}{l}\text { Most extensively } \\
\text { performed breast } \\
\text { surgery }\end{array}$ & $\begin{array}{l}\text { Modified radical } \\
\text { mastectomy }\end{array}$ & $\begin{array}{l}\text { Breast segment } \\
\text { resection }\end{array}$ & $\begin{array}{l}\text { Modified } \\
\text { radical } \\
\text { mastectomy }\end{array}$ & $\begin{array}{l}\text { Modified } \\
\text { radical } \\
\text { mastectomy }\end{array}$ \\
\hline $\begin{array}{l}\text { Breast tumor } \\
\text { histological subtype }\end{array}$ & $\mathrm{ILC}^{1}$ & $\mathrm{IDC}^{2}$ & IDC & IDC \\
\hline $\begin{array}{l}\text { Scarff-Bloom- } \\
\text { Richardson grade }\end{array}$ & प & प & II & प \\
\hline Tumor stage & $\mathrm{T}_{2}$ & $\mathrm{~T}_{2}$ & $\mathrm{~T}_{2}$ & $\mathrm{~T}_{2}$ \\
\hline Nodal stage & $\mathrm{N}_{2}$ & $\mathrm{~N}_{2}$ & $\mathrm{~N}_{0}$ & $\mathrm{~N}_{0}$ \\
\hline Metastasis & 0 & 1 & 0 & 1 \\
\hline TNM stage & Illa & IV & Ila & IV \\
\hline $\begin{array}{l}\text { Estrogen receptor } \\
\text { (Primary } \\
\text { tumor/Metastasis } \\
\text { tumor) }\end{array}$ & Positive / Positive & $\begin{array}{l}\text { Positive / } \\
\text { Positive }\end{array}$ & $\begin{array}{l}\text { Positive / } \\
\text { Positive }\end{array}$ & $\begin{array}{l}\text { Positive / } \\
\text { Positive }\end{array}$ \\
\hline $\begin{array}{l}\text { Progesterone receptor } \\
\text { (Primary } \\
\text { tumor/Metastasis } \\
\text { tumor) }\end{array}$ & Positive / Positive & $\begin{array}{l}\text { Positive / } \\
\text { Negative }\end{array}$ & $\begin{array}{l}\text { Negative / } \\
\text { Negative }\end{array}$ & $\begin{array}{l}\text { Negative / } \\
\text { Positive }\end{array}$ \\
\hline $\begin{array}{l}\text { Her2/neu receptor } \\
\text { (Primary } \\
\text { tumor/Metastasis } \\
\text { tumor) }\end{array}$ & Negative / Negative & $\begin{array}{l}\text { Positive / } \\
\text { Positive }\end{array}$ & $\begin{array}{l}\text { Negative / } \\
\text { Negative }\end{array}$ & $\begin{array}{l}\text { Negative / } \\
\text { Negative }\end{array}$ \\
\hline $\begin{array}{l}\text { Ki-67 (Primary } \\
\text { tumor/Metastasis } \\
\text { tumor) (\%) }\end{array}$ & $20 / 30$ & $50 / 50$ & $25 / 50$ & $90 / 20$ \\
\hline BRCA $1 / 2$ & Negative / Negative & $\begin{array}{l}\text { Negative / } \\
\text { Negative }\end{array}$ & $\begin{array}{l}\text { Negative / } \\
\text { Negative }\end{array}$ & $\begin{array}{l}\text { Negative / } \\
\text { Negative }\end{array}$ \\
\hline $\begin{array}{l}\text { Molecular subtypes } \\
\text { (Primary tumor) }\end{array}$ & Luminal B & Luminal B & Luminal B & Luminal B \\
\hline $\begin{array}{l}\text { Postoperative } \\
\text { pathology }\end{array}$ & ILC & IDC & IDC & IDC \\
\hline
\end{tabular}




\begin{tabular}{|c|c|c|c|c|}
\hline Characteristics & Case 1 & Case 2 & Case 3 & Case 4 \\
\hline $\begin{array}{l}\text { Postoperative } \\
\text { treatment of primary } \\
\text { tumor }\end{array}$ & $\begin{array}{l}\text { Cyclophosphamide } \\
+ \text { epirubicin + } \\
\text { fluorouracil IV } \\
\text { Anastrozole }\end{array}$ & $\begin{array}{l}\text { Docetaxel } \\
\text { Trastuzumab } \\
\text { Letrozole }\end{array}$ & $\begin{array}{l}\text { Docetaxel + } \\
\text { carboplatin } \\
\text { IV + } \\
\text { carboplatin } \\
\text { IP4 }\end{array}$ & $\begin{array}{l}\text { Paclitaxel + } \\
\text { carboplatin IP } \\
\text { Chest wall } \\
\text { radiotherapy } \\
\text { Letrozole }\end{array}$ \\
\hline $\begin{array}{l}\text { Age at diagnosis of } \\
\text { peritoneal metastases, } \\
\text { years }\end{array}$ & 64 & 60 & 65 & 50 \\
\hline $\begin{array}{l}\text { Time between breast } \\
\text { cancer and peritoneal } \\
\text { metastases, months }\end{array}$ & 174 & 0 & 120 & 0 \\
\hline Clinical presentation & $\begin{array}{l}\text { Abdominal } \\
\text { distension }\end{array}$ & $\begin{array}{l}\text { Frequent } \\
\text { urination, } \\
\text { constipation and } \\
\text { abdominal pain }\end{array}$ & $\begin{array}{l}\text { Abdominal } \\
\text { pain and } \\
\text { abdominal } \\
\text { distension }\end{array}$ & $\begin{array}{l}\text { Left breast } \\
\text { mass and } \\
\text { abdominal } \\
\text { distension }\end{array}$ \\
\hline $\begin{array}{l}\text { Diagnosis of } \\
\text { peritoneal metastasis }\end{array}$ & $\begin{array}{l}\text { Postoperative } \\
\text { pathology }\end{array}$ & $\begin{array}{l}\text { Postoperative } \\
\text { pathology }\end{array}$ & $\begin{array}{l}\text { Postoperative } \\
\text { pathology }\end{array}$ & Needle biopsy \\
\hline \multicolumn{5}{|c|}{ 1. Invasive lobular carcinoma } \\
\hline \multicolumn{5}{|c|}{ 2. Invasive ductal carcinoma } \\
\hline \multicolumn{5}{|l|}{ 3. Intravenous } \\
\hline 4. Intraperitoneal & & & & \\
\hline
\end{tabular}

\section{Major characteristics of CRS + HIPEC}

The average time of CRS + HIPEC was $8.8 \mathrm{~h}$ (range: 7-10.6 h). The median number of resected organs was 7 (range: 5-9). The average blood loss was $525 \mathrm{ml}$ (range: $400-800 \mathrm{ml}$ ). The average ascites volume was $3,625 \mathrm{ml}$ (range: $1,000-10,000 \mathrm{ml}$ ). In regard to HIPEC regimen, all 4 cases were with docetaxel $120 \mathrm{mg}$ plus cisplatin $120 \mathrm{mg}$. The average $\mathrm{PCl}$ was 29.5 (range: 21-39). The case 1 and case 2 reached to $\mathrm{CC} 0$. The case 3 and case 4 only reached to CC 3. The major clinicopathological characteristics of CRS + HIPEC were showed in Table 2. 
Table 2

Major clinicopathological characteristics of CRS + HIPEC

\begin{tabular}{|c|c|c|c|c|}
\hline Characteristics & Case 1 & Case 2 & Case 3 & Case 4 \\
\hline $\begin{array}{l}\text { Peritoneal } \\
\text { cancer index } \\
\text { (PCI) }\end{array}$ & 39 & 28 & 21 & 30 \\
\hline $\begin{array}{l}\text { Completeness } \\
\text { of } \\
\text { cytoreduction } \\
\text { (CC) }\end{array}$ & 3 & 3 & 0 & 0 \\
\hline $\begin{array}{l}\text { Karnofsky } \\
\text { performance } \\
\text { status (KPS) }\end{array}$ & 80 & 80 & 80 & 80 \\
\hline $\begin{array}{l}\text { Blood loss } \\
(\mathrm{ml})\end{array}$ & 400 & 800 & 400 & 500 \\
\hline $\begin{array}{l}\text { Rang of } \\
\text { operation }\end{array}$ & $\begin{array}{l}\text { Omentum, uterus, } \\
\text { bilateral fallopian } \\
\text { tubes, ovary, } \\
\text { bladder tumor, } \\
\text { hepatic round } \\
\text { ligament, } \\
\text { abdominal wall } \\
\text { mass }\end{array}$ & $\begin{array}{l}\text { abdominal } \\
\text { wall tumor, } \\
\text { intestinal } \\
\text { repair, } \\
\text { omentum, } \\
\text { retroperitoneal } \\
\text { tumor, breast } \\
\text { segment }\end{array}$ & $\begin{array}{l}\text { rectal, mesenteric, } \\
\text { appendectomy, small } \\
\text { bowel, diaphragm lesions, } \\
\text { omentum lesion, total } \\
\text { hysterectomy, bowel repair, } \\
\text { omentectomy and pelvic } \\
\text { lymphadenectomy }\end{array}$ & $\begin{array}{l}\text { total uterus, } \\
\text { double } \\
\text { attachment, } \\
\text { omentum, } \\
\text { para-aortic } \\
\text { lymph nodes, } \\
\text { pelvic lymph } \\
\text { nodes }\end{array}$ \\
\hline $\begin{array}{l}\text { Chemotherapy } \\
\text { drugs for } \\
\text { HIPEC }\end{array}$ & $\begin{array}{l}\text { Docetaxel + } \\
\text { Cisplatin }\end{array}$ & $\begin{array}{l}\text { Docetaxel + } \\
\text { Cisplatin }\end{array}$ & Docetaxel + Cisplatin & $\begin{array}{l}\text { Docetaxel + } \\
\text { Cisplatin }\end{array}$ \\
\hline $\begin{array}{l}\text { Operation } \\
\text { duration (h) }\end{array}$ & 7.0 & 10.6 & 9.0 & 8.5 \\
\hline $\begin{array}{l}\text { HIPEC } \\
\text { duration (min) }\end{array}$ & 60 & 60 & 60 & 60 \\
\hline $\begin{array}{l}\text { Ascites } \\
\text { volume (ml) }\end{array}$ & 10000 & 2000 & 1000 & 1500 \\
\hline $\begin{array}{l}\text { Ascites } \\
\text { properties }\end{array}$ & $\begin{array}{l}\text { Light yellow } \\
\text { slightly turbid }\end{array}$ & Light yellow & Yellow turbid & Light yellow \\
\hline \multirow[t]{3}{*}{$\begin{array}{l}\text { Postoperative } \\
\text { treatment }\end{array}$} & \multirow[t]{3}{*}{ Letrozole } & $\begin{array}{l}\text { Docetaxel } \\
\text { Trastuzumab }\end{array}$ & $\begin{array}{l}\text { Docetaxel + carboplatin IV } \\
\text { Letrozole }\end{array}$ & $\begin{array}{l}\text { Paclitaxel + } \\
\text { carboplatin } \\
\text { IP }\end{array}$ \\
\hline & & Letrozole & & $\begin{array}{l}\text { Chest wall } \\
\text { radiotherapy }\end{array}$ \\
\hline & & & & Letrozole \\
\hline $\begin{array}{l}\text { Operative } \\
\text { complications }\end{array}$ & NO & NO & NO & NO \\
\hline
\end{tabular}




\begin{tabular}{|lllll|}
\hline Characteristics & Case 1 & Case 2 & Case 3 & Case 4 \\
\hline $\begin{array}{l}\text { The average } \\
\text { hospital stay } \\
\text { after CRS + }\end{array}$ & 15 & 10 & 21 & 12 \\
HIPEC (d) & 205 & 28 & 136 & 52 \\
$\begin{array}{l}\text { Overall } \\
\text { survival from } \\
\text { diagnosis BC } \\
\text { to last follow- } \\
\text { up date (OS } 1 \text { ) } \\
\text { (month) }\end{array}$ & 28 & & \\
\hline $\begin{array}{l}\text { Overall } \\
\text { survival from } \\
\text { CRS + HIPEC } \\
\text { to last follow- } \\
\text { up date (OS } 2) \\
\text { (month) }\end{array}$ & 31 & 16 & 52 \\
\hline
\end{tabular}

\section{OS and safety analysis}

All 4 patients were alive and $\mathrm{OS}_{2}$ were $31,28,16$ and 52 months, respectively. $\mathrm{OS}_{1}$ was $205,28,136$ and 52 months, respectively. (Table 2 )

Case 1 appeared incision liquefaction after CRS + HIPEC and no adverse events occurred in the other 3 cases. There were no SAEs such as gastrointestinal fistula, bleeding during the perioperative period.

\section{Discussion}

Our study introduces the detailed process of CRS + HIPEC and demonstrates that patients with BC PC can benefit from the treatment. CRS + HIPEC extends OS of BC PC patients. There are no SAEs during CRS + HIPEC perioperative period.

The most common metastasis sites of primary BC with invasive ductal carcinoma (IDC) include regional lymph nodes, lung, liver, bones, brain, and skin. BC with invasive lobular carcinoma (ILC) frequently affects bones, retroperitoneum, peritoneum, gynaecological organs, and gastrointestinal (GI) tract [1516]. ILC accounts for less than $10 \%$ of all BCs and ICD accounts for more than $90 \%$. However, the loss of E-cadherin expression on the surface of tumor cells in ILC patients leads to more diverse forms of metastasis. It prevents cell adhesion and promotes tumor cell migration [17]. Peritoneal metastasis can be diagnosed by CT or surgery. IDC patients account for only $3 \%$ while ILC patients account for $11 \%$ ( $P=$ 0.006). Regardless of IDC or ILC, PC is an important reason of morbidity and mortality [18]. In our study, there were 1 patient with ILC and 3 patients with IDC of the primary BC (Fig. 2-4). The metastasis tumor and the primary tumor had the same pathological type. 
The prognosis of PC showed poor survival than other regional metastases from BC. The median survival time was 20.5 months from diagnosis of metastasis $B C$ while the median survival of patients with $B C P C$ was only 1.5 months [19]. Another study showed the OS was 5.8 months in patients with BC PC from the metastasis PC was diagnosed as compared to 22.6 months in patients with no metastasis PC. Patients with synchronous metastases have significantly better survival than those with metachronous metastases [20]. There were 2 cases with metachronous metastases and 2 cases with synchronous metastases in our study. The OS of the synchronous metastases' patients had reached 28 months and the longest OS of the metachronous metastases had reached 52 months to March 2020.

BC PC caused abdominal distension, abdominal pain or severe intestinal obstruction. And all patients in our study had at least one of the above symptoms. However, there were no effective treatments to relieve these symptoms and chronic malnutrition caused poor prognosis. The traditional treatment methods for BC PC were chemotherapy or radiotherapy but the effect of the treatment was unsatisfactory. The treatment of BC PC in our study was CRS + HIPEC combined with chemotherapy. To achieve radical CRS, the median number of resected organs were 7 and 2 patients reached $C C 0$. The tolerance to hyperthermia was higher in normal tissue than the tumor tissue. HIPEC could prevent the adhesion postoperatively, as well as decrease the accelerative effect of healing on tumor cell entrapment by killing the granulocytes and monocytes. The synergistic anti-cancer effect could be dramatically increased at $43^{\circ} \mathrm{C}$. Hyperthermia could increase the response rates of cancer cells to HIPEC drugs, and the depth of HIPEC drugs into the tumor tissues. At last, loosening the adhesion of the intestine or ileostomy could relieve the intestinal obstruction. In our study, one case underwent loosening the adhesion of the intestine, and another underwent ileostomy, the abdominal distension or bowel obstruction of which relieved completely. All patients in our study received adjuvant chemotherapy and endocrine therapy pre- and post-CRS + HIPEC. The average OS reached 32 months better than literature [4].

Estrogen played an important role in the occurrence and prognosis of BC. The estrogen receptor (ER) was one of the important biomarkers to predict the prognosis of $\mathrm{BC}$ [21]. BC patients with ER- and progesterone receptor (PR)- positive had a better prognosis [22]. Human epidermal growth factor receptor 2 (HER-2) regulates cell proliferation, growth, and survival. HER-2 was a transmembrane tyrosine kinase receptor [23-24]. BC patients with high levels $\mathrm{Ki}-67$ usually have a poor prognosis due to $\mathrm{Ki}-67$ was a nuclear proliferation marker [25]. In our study, two patients with synchronous BC PC, one with Ki-67 80$90 \%$ and another with HER-2 positive, maybe one of the reasons for the early peritoneal metastasis. The other two cases received standard adjuvant therapy after the primary lesion. All patients received tamoxifen treatment for 5 years and metastasis occurred after 5 years of discontinuation (all 4 cases had positive estrogen receptors). It was necessary to receive estrogen therapy for hormone receptor-positive BC PC patients after CRS + HIPEC. At present, all the 4 patients had received letrozole orally after CRS + HIPEC and chemotherapy. No tumor progression occurred at the time of follow-up. 
The average $\mathrm{PCl}$ was 29.5 , which heralded the difficulty of CRS. The average operation duration was $8.8 \mathrm{~h}$ and average 7 organs were resected. The average blood loss was $525 \mathrm{ml}$ and the average ascites volume was $3,625 \mathrm{ml}$. While there were no SAEs during the perioperative period and the average hospital stay was $15 \mathrm{~d}$. The safety of CRS + HIPEC was accepted. It was important that a professional PC treatment team implemented standardised CRS + HIPEC. Otherwise, you maybe come to the opposite conclusion that CRS + HIPEC was not the treatment of choice [26]. This article provided new ideas and methods for the treatment of BC PC patients. This finding merits further investigation in larger studies.

The disadvantage of this study was that the number of patients was too small to perform statistical analysis. The follow-up time was short, no comparison with a control group and lack of questionnaires to evaluate quality of life (QoL). Therefore, these findings in this study required more confirmations from a large sample of evidence.

\section{Conclusions}

This paper reported 4 typical cases of BC PC successfully treated by a radical comprehensive treatments with CRS + HIPEC. These patients kept in good condition till now, with 32 months of mean $\mathrm{OS}_{2}$. The 4 cases provided evidence that integrated therapy with CRS + HIPEC may be a promising strategy to improve the outcome for BC PC patients.

\section{List Of Abbreviations}




\begin{tabular}{|ll|}
\hline BC & Breast cancer \\
\hline CRS & Cytoreductive surgery \\
\hline HIPEC & Hyperthermic intraperitoneal chemotherapy \\
\hline PC & Peritoneal carcinomatosis \\
\hline BC PC & Breast cancer peritoneal carcinomatosis \\
\hline SAEs & Serious adverse events \\
\hline IDC & Invasive ductal carcinoma \\
\hline ILC & Invasive lobular carcinoma \\
\hline GI & Gastrointestinal \\
\hline KPS & Karnofsky performance status \\
\hline ULN & Upper limit of normal \\
\hline PCI & Peritoneal cancer index \\
\hline CC & Completeness of cytoreduction \\
\hline OS & Overall survival \\
\hline CT & Computed tomography \\
\hline ER & Estrogen receptor \\
\hline PR & Progesterone receptor \\
\hline HER-2 & Human epidermal growth factor receptor 2 \\
\hline IV & Intravenous \\
\hline IP & Intraperitoneal \\
\hline IC & Intermediate care \\
\hline ICU & Intensive care unit \\
\hline QoL & Quality of life \\
\hline
\end{tabular}

\section{Declarations}

Ethics approval and consent to participate

Not applicable.

Consent for publication 
Written informed consent was obtained from the 4 patients for publication of this article and accompanying images. A copy of these written consent is available for review by the Editor-in-Chief of this journal.

\section{Availability of data and material}

The datasets used and analysed during the current study are available from the corresponding author on reasonable request.

\section{Competing interests}

The authors declare that they have no competing interests.

\section{Funding}

This work was supported by the Beijing Municipal Administration of Hospital Ascent Plan (DFL20180701); Beijing Municipal Grant for Medical Talents Group on Peritoneal Surface Oncology (2017400003235J007) (both to Yan Li).

\section{Authors' contributions}

Jun-hui Yu organised the patient's medical records and was the major contributor in writing the manuscript.

Yu Feng, Xin-bao Li and Yan-Ping Li collected the patient's medical records.

Cheng-Yan Zhang and Feng Shi collected the patient's pathological pictures.

Song-Lin An, Gang Liu, Yan-Bin Zhang, Kai Zhang, Zhong-He Ji, Bing Li and Guo-Jun Yan conducted the procedures of CRS + HIPEC.

Yan Li designed the project, monitored project progress, and contributed to data evaluation of the manuscript.

\section{Acknowledgement}

Not applicable.

\section{References}

1. Chen W, Zheng R, Baade PD, Zhang S, Zeng H, Bray F, Jemal A, Yu XQ, He J. Cancer statistics in China, 2015. CA Cancer J Clin. 2016; 66: 115-32.

2. Ghoncheh M, Pournamdar Z, Salehiniya H. Incidence and mortality and epidemiology of breast cancer in the world. Asian Pac J Cancer Prev. 2016; 17(3): 43-6. 
3. Kouloulias V, Triantopoulou S, Uzunoglou N, Pistevou-Gompaki K, Barich A, Zygogianni A, Kyrgias G, Kardamakis D, Pectasidis D, Kouvaris J, Greek Society of Hyperthermic Oncology. Hyperthermia is now included in the NCCN clinical practice guidelines for breast cancer recurrences: an analysis of existing data. Breast Care. 2015; 10(2): 109-16.].

4. Bertozzi S, Londero AP, Cedolini C, Uzzau A, Seriau L, Bernardi S, Bacchetti S, Pasqual EM, Risaliti A. Prevalence, risk factors, and prognosis of peritoneal metastasis from breast cancer. Springerplus. 2015; 4(1): 688.

5. McLemore EC, Pockaj BA, Reynolds C, Gray RJ, Hernandez JL, Grant CS, Donohue JH. Breast cancer: presentation and intervention in women with gastrointestinal metastasis and carcinomatosis. Ann Surg Oncol. 2005; 12(11): 886-94.

6. Pasqual EM, Bertozzi S, Londero AP, Brandolin D, Mariuzzi L, De Pellegrin A, Bacchetti S, Zoratti L, Petri R, Della Bianca C, Snidero D, Terrosu G, Uzzau A, Risaliti A, Di Loreto C, Pizzolitto S, Zilli M, de Manzoni G. Microscopic peritoneal carcinomatosis in gastric cancer: prevalence, prognosis and predictive factors. Oncol Lett. 2018; 15(1): 710-6.

7. Bertozzi S, Londero AP, Cedolini C, Uzzau A, Seriau L, Bernardi S, Bacchetti S, Pasqual EM, Risaliti A. Prevalence, risk factors, and prognosis of peritoneal metastasis from breast cancer. Springerplus. 2015; 4(1): 688.

8. Yan Li, Yun-Feng Zhou, Han Liang, Hua-Qing Wang, Ji-Hui Hao, Zheng-Gang Zhu, De-Seng Wan, LunXiu Qin, Shu-Zhong Cui, Jia-Fu Ji, Hui-Mian Xu, Shao-Zhong Wei, Hong-Bin Xu, Tao Suo, Shu-Jun Yang, Cong-Hua Xie, Xiao-Jun Yang, Guo-Liang Yang. Chinese expert consensus on cytoreductive surgery and hyperthermic intraperitoneal chemotherapy for peritoneal malignancies. World $\mathrm{J}$ Gastroenterol. 2016; 22(30): 6906-16.

9. Jacquet $\mathrm{P}$, Sugarbaker $\mathrm{PH}$. Clinical research methodologies in diagnosis and staging of patients with peritoneal carcinomatosis. Cancer Treat Res. 1996; 82: 359-74.

10. Sugarbaker PH. Peritonectomy procedures. Ann Surg. 1995; 221(1): 29-42.

11. Sugarbaker PH. Cytoreductive surgery and peri-operative intraperitoneal chemotherapy as a curative approach to pseudomyxoma peritonei syndrome. Eur J Surg Oncol. 2001; 27(3): 239-43.

12. Li XB, Ma R, Ji ZH, Lin YL, Zhang J, Yang ZR, Chen LF, Yan FC, Li Y. Perioperative safety after cytoreductive surgery plus hyperthermic intraperitoneal chemotherapy for pseudomyxoma peritonei from appendiceal origin: Experience on 254 patients from a single center. Eur J Surg Oncol. 2020; 46(4 Pt A): 600-6.

13. Clavien PA, Sanabria JR, Strasberg SM. Proposed classification of complications of surgery with examples of utility in cholecystectomy[J]. Surgery, 1992,111(5) : 518-26.

14. Dindo D, Demartines N, Clavien PA. Classification of surgical complications: a new proposal with evaluation in a cohort of 6336 patients and results of a survey[J]. Ann Surg, 2004,240(2) : 205-13.

15. Solomayer EF, Diel IJ, Meyberg GC, Gollan C, Bastert G. Metastatic breast cancer: clinical course, prognosis and therapy related to the first site of metastasis. Breast Cancer Res Treat. 2000; 59(3): 271-8. 
16. Arrangoiz R, Papavasiliou P, Dushkin H, Farma M. Case report and literature review: metastatic Iobular carcinoma of the breast an unusual presentation. Int J Surg Case Rep. 2011; 2(8): 301-5.

17. Ciriello G, Gatza ML, Beck AH, Wilkerson MD, Rhie SK, Pastore A, Zhang H, McLellan M, Yau C, Kandoth C, Bowlby R, Shen H, Hayat S, Fieldhouse R, Lester SC, Tse G, Factor RE, Collins LC, Allison $\mathrm{KH}$, Chen YY, Jensen K, Johnson NB, Oesterreich S, Mills GB, Cherniack AD, Robertson G, Benz C, Sander C, Laird PW, Hoadley KA, King TA, Perou CM. Comprehensive molecular portraits of invasive lobular breast cancer. Cell. 2015; 163(2): 506-19.

18. Inoue M, Nakagomi H, Nakada H, Furuya K, Ikegame K, Watanabe H, Omata M, Oyama T. Specific sites of metastases in invasive lobular carcinoma: a retrospective cohort study of metastatic breast cancer. Breast Cancer. 2017; 24(5): 667-72.

19. Tuthill M, Pell R, Guiliani R, Lim A, Gudi M, Contractor KB, Lewis JS, Coombes RC, Stebbing J. Peritoneal disease in breast cancer: a specific entity with an extremely poor prognosis. Eur $\mathrm{J}$ Cancer. 2009; 45(12): 2146-9.

20. Flanagan M, Solon J, Chang KH, Deady S, Moran B, Cahill R, Shields C, Mulsow J. Peritoneal metastases from extra-abdominal cancer - a population-based study. Eur J Surg Oncol. 2018; 44(11): 1811-7.

21. Fragomeni S M, Sciallis A, Jeruss J S. Molecular subtypes and local-regional control of breast cancer. Surg Oncol Clin N Am. 2018; 27(1): 95-120.

22. Oudanonh T, Nabi H, Ennour-Idrissi K, Lemieux J, Diorio C. Progesterone receptor status modifies the association between body mass index and prognosis in women diagnosed with estrogen receptor positive breast cancer. Int J Cancer. 2020; 146(10): 2736-45.

23. Kim MH, Kim GM, Kim JH, Kim JY, Park HS, Park S, Cho YU, Park BW, Kim SI, Sohn J. Intermediate HER2 expression is associated with poor prognosis in estrogen receptor-positive breast cancer patients aged 55 years and older. Breast Cancer Res Treat. 2020; 179(3): 687-97.

24. Harbeck N, Gnant M. Breast cancer. Lancet. 2017; 389(10074): 1134-50.

25. Dumanskiy YV, Bondar OV, Stoliarchuk EA. The Ki-67 marker for assessing the effectiveness of systemic or regional neoadjuvant polychemotherapy in patients with locally advanced breast cancer. Exp Oncol. 2019; 41(2): 176-8.

26. Beniey M. Peritoneal metastases from breast cancer: a scoping review. Cureus. 2019; 11(8): e5367.

\section{Figures}




\section{Peritoneal Cancer Index (PCI)}

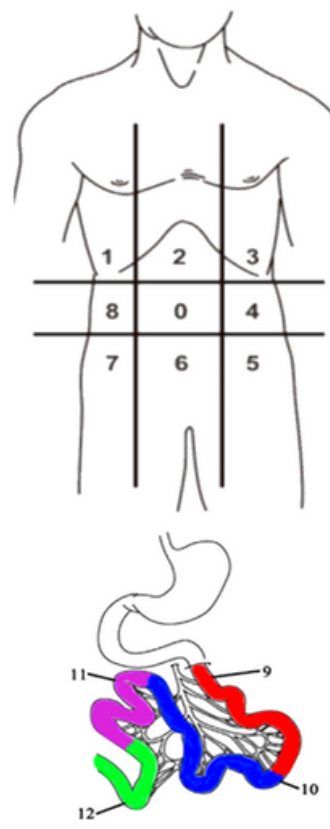

Lesion Size Score

LS-0 No tumor seen

LS-1 Tumor up to $0.5 \mathrm{~cm}$

LS-2 Tumor up to $5.0 \mathrm{~cm}$

LS-2 Tumor $>5.0 \mathrm{~cm}$ or confluence

$\underline{\text { Regions }}$

0 Central

1 Right Upper

2 Epigastrium

3 Left Upper

4 Left Flank

5 Left Lower

6 Pelvis

7 Right Lower

8 Right Flank

9 Upper Jejunum

10 Lower Jejunum

11 Upper Ileum

12 Lower Ileum

\section{PCI}

\section{B}

Completeness of Cytoreduction (CC)

CC-0

No disease

CC-1

$==ニ=0$

Present to $0.25 \mathrm{~cm}$

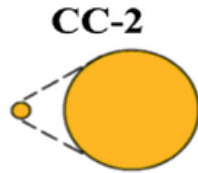

$0.25 \mathrm{~cm}$ to $2.5 \mathrm{~cm}$

$>2.5 \mathrm{~cm}$

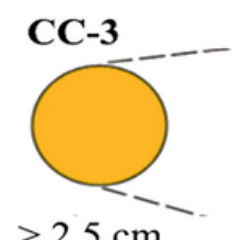

Figure 1

Peritoneal cancer index score (A) and completeness of cytoreduction score (B).
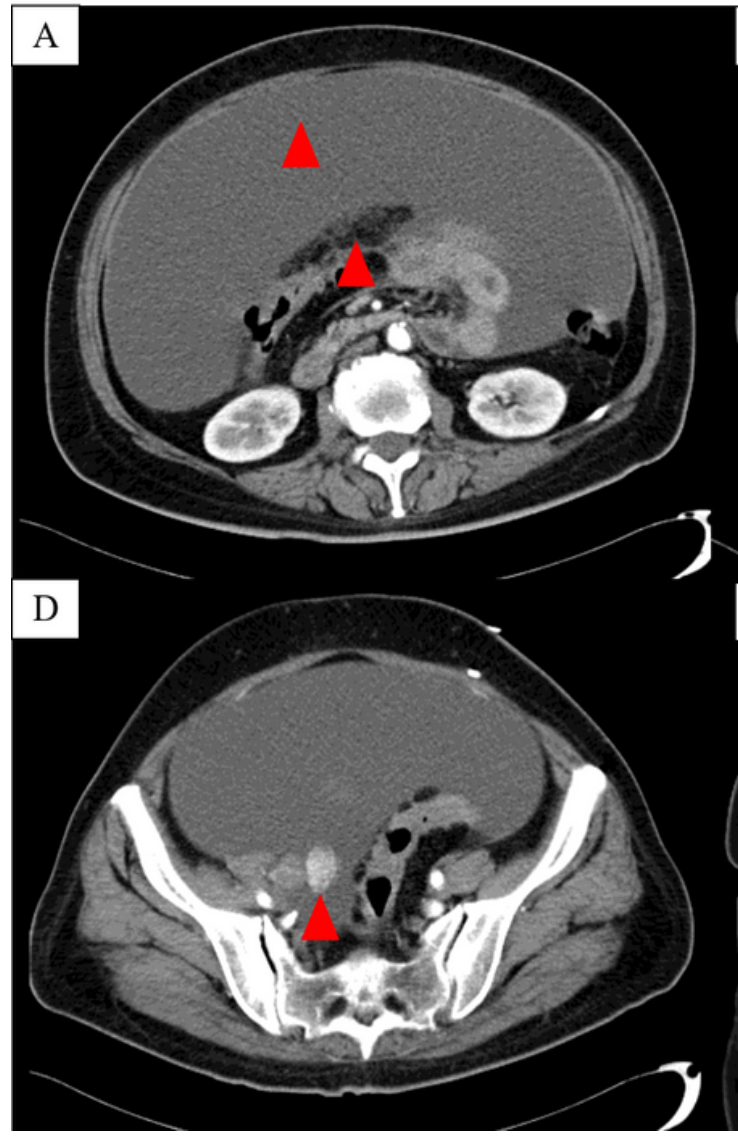

\section{Lesion Size}

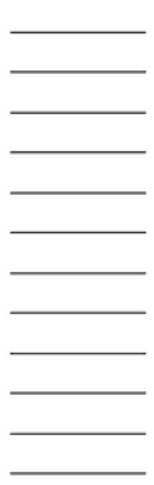




\section{Figure 2}

Preoperative image examination. A: Massive ascites and omentum contraction; B: Small intestine contraction; C: Peritoneal thickening; D: Pelvic tumor with contrast enhancement; E: Coronal showed Massive ascites; omentum contraction and small intestine contraction; F: Total gastrointestinal angiography showed the gathered small intestine.

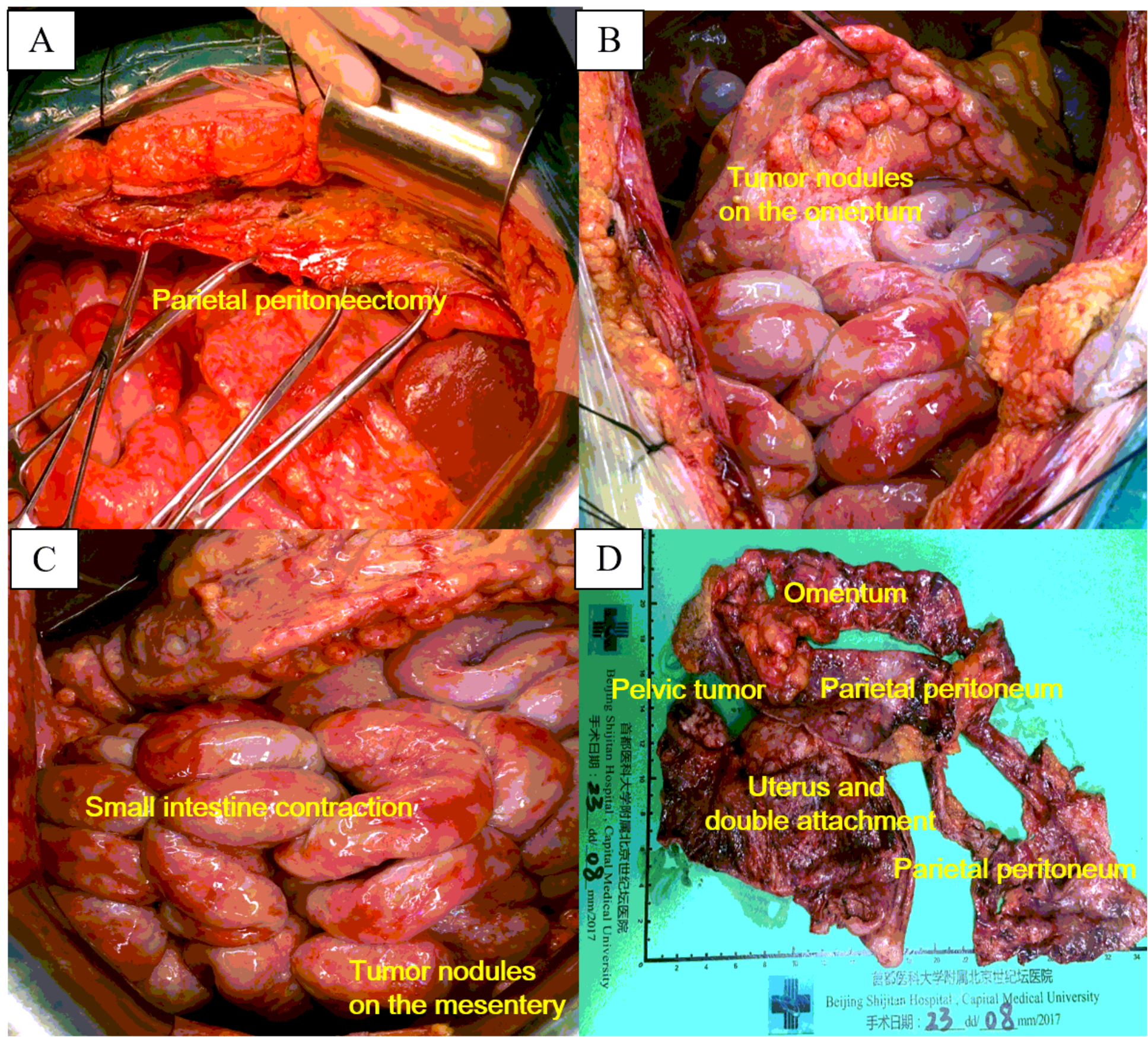

\section{Figure 3}

CRS intraoperative and postoperative specimens. A: Omentum contraction; B: Tumor nodules on the omentum; C: Small intestine contraction and tumor nodules on the mesentery; D: Postoperative specimens. 


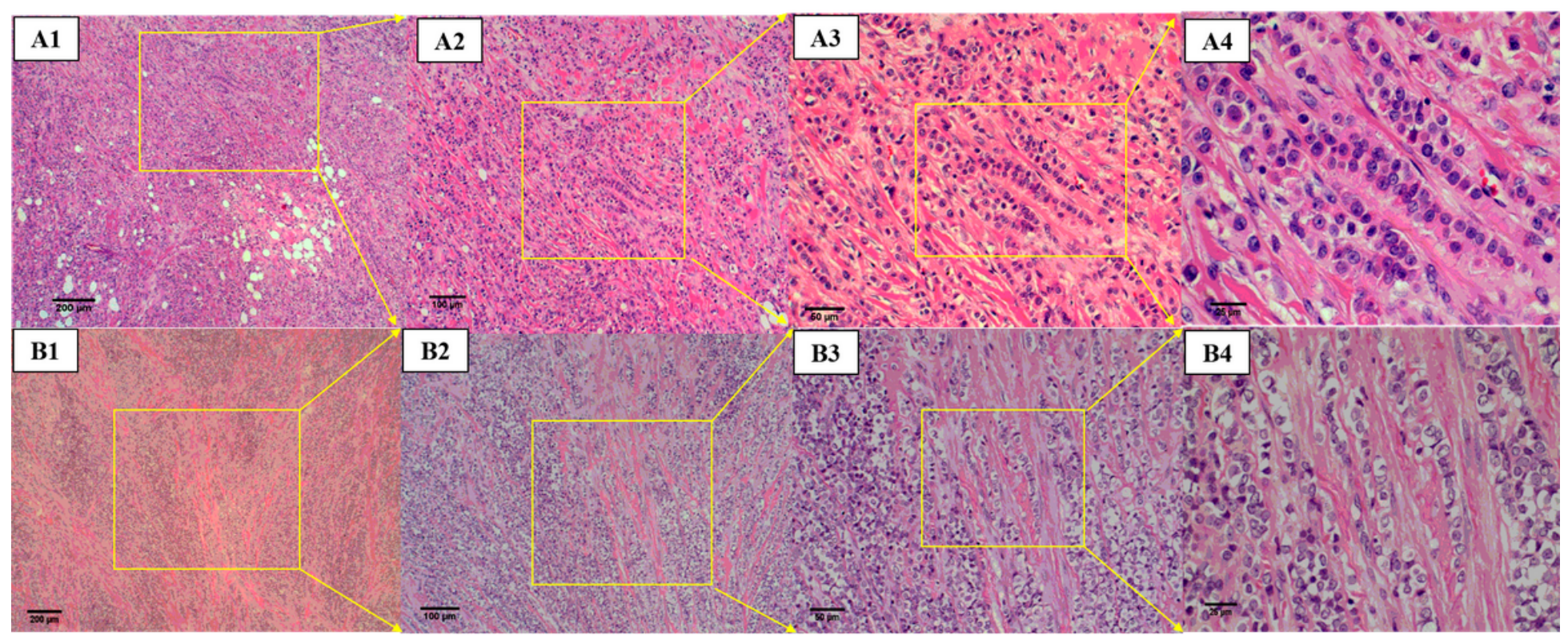

Figure 4

Pathological classification of primary (A1 - A4) and metastasis (B1 - B4) breast tumors (hematoxylineosin staining). A1: Invasive lobular carcinoma of the breast; A2: Tumor cells have poor adhesion and scattered in a single or single row of infiltrating interstitium; A3: Tumor cells infiltrate the stroma in a single row and forming a linear structure; A4: Tumor cells have smaller but the same size. Some cytoplasm contains eosinophilic globules and the nucleus is eccentric, round, small nucleolus and pathological mitosis are rare. B1: Invasive lobular carcinoma metastasises to the abdominal cavity and infiltrates into the peritoneal fibrous connectives; B2: Tumor cells have poor adhesion, diffuse, scattered in a single or single row of infiltrating interstitium; B3: Tumor cells infiltrate the stroma in a single row and forming a linear structure; B4: Tumor cells have the same size, nuclear round, small nucleoli are common and pathological mitosis is rare. The magnification of the pictures of the two-line from the left to right are $\times 50, \times 100, \times 200$ and $\times 400$, respectively. 